\title{
EDUCATION LOAN REPAYMENT AND PERFORMANCES: THE MALAYSIAN GRADUATES PERSPECTIVES
}

\author{
Edward Wong Sek Khin, Ahmad Nasharuddin and Kamisah Binti Ismail \\ Faculty of Business and Accountancy \\ University of Malaya, Malaysia \\ (edwardwong@um.edu.my)
}

\begin{abstract}
This study examined the factors that encouraged and influenced the intention to make repayment of education loan, National Higher Education Fund Corporation (PTPTN) in Malaysia. The study adapted the Theory of Reasoned Action (TRA) based on the study of Fishbein and Ajzen (1980) whose aim was mainly to predict the attitudinal influence and behavioural intention. In order to investigate people's thinking process that leads to the decision of repayment, the study would be a descriptive study based on 300 participants who graduated from one of the public universities in Malaysia. The correlation analysis resulted from this study confirmed previous researchers' observations that linked higher educational loan repayment commitments with a higher ability to predict attitudinal influence and behavioural intention. The results suggested that among the three factors namely; attitude towards education loan repayment; perception of affordability of loan repayment that affects the quality of life after graduation, and perception towards loan agreements were the most important predictors of repayment of education loan management. The findings from this study could assist the National Higher Education Fund Corporation (PTPTN) to understand further their borrower insights in paying back loans owed. The knowledge can also assist policymakers to understand better specific strategies, approaches and other relevant matters in making sure that borrowers comply with the repayment conditions while not being a burden to both government and the public.
\end{abstract}

Key words: Education loan repayment, Theory of reasoned action, attitudinal influence, and behavioural intention. 


\section{Introduction}

There seem to be a never-ending debate over the National Higher Education Fund Corporation (PTPTN) student loans whether it is a burden or a blessing towards students in Malaysia. As more and more new higher education establishments are emerging in Malaysia in the form of public and private institutions, there are more opportunities created for students to enroll themselves to pursue higher or tertiary education level. As mentioned by Zainal and Ismail (2012), the Malaysian higher education sector has been growing tremendously for the past ten years or so. The ever-increasing number of enrollment in both public and private institutions indicates that the trend is growing year by year. This result is primarily due to the large number of student loans provided by the National Higher Education Fund Corporation (PTPTN) (Zainal and Ismail, 2012).

The increase in some students and higher learning institutions has resulted in a shortage of scholarships that are available to the students by the relevant agencies. This has created a gap solved only by the government providing education loans to the students. This financial aid has become a necessity for students who wish to continue their studies (Abu Bakar et al., 2006). Despite the government efforts to help students in achieving tertiary education, many students tend to take it for granted. As the numbers of borrowers grow, the repayment from graduates is very much lower than expected. PTPTN had some 11,956 borrowers in 1997, and some borrowers have been increasing year-by-year. The amount borrowed since that time has ballooned to RM 1.69 million (cumulative) as of 31 December 2010, and the total amount of PTPTN loans is a cumulative RM 37.4 billion.

This has come to no surprise, as PTPTN has been the driver for students to seek a higher level of education in Malaysia. Despite the fact that it is a public financial educational assistance, this does not mean that students who borrowed from the PTPTN will expect a full subsidy from the government. This would mean that no one has to repay the loan. If this were the case, there is no need for the establishment of PTPTN and a free education system would prevail. Borrowers need to remember that the fund needs replenishment or else it will create burdens and consequences in the future. According to Ismail, Serguieva, and Singh (2011), Malaysia is one of the countries that have a high loan default rate. Although recent trends are showing an increase in repayments, it is still not enough to sustain the funds required for the future. The inadequacy of repayments may result in stricter rules and regulation by the four policymakers, and it might cause major 
changes to minimise and address loan defaulters. By achieving the understanding of graduates towards the repayment of the loans, it can help PTPTN to replenish their funds for future generation. PTPTN has coordinated many efforts to achieve this goal. Among the initiatives taken include engaging with the public/students, as well as giving discounts to graduates with consistent repayment. This also includes the recently proposed blacklisting of loan defaulters under the Bank Negara's Central Credit Reference Information System (CCRIS) (Ghazali, 2013). This would require new measures and commitments from all relevant parties to transform and ensure that the National Higher Education Fund Corporation is sustainable for future generations. Therefore, this study will identify the factors that influence the repayment intention of education loans among graduates in Malaysia.

This study seeks to answer the following research questions:

- What are the factors influencing intention of loan re-payment among graduates?

- Do the graduates' attitudes and perceptions towards PTPTN loans and the repayment of PTPTN loans affect the intention to pay?

\section{Literature Review \\ Tertiary education}

The importance of higher or tertiary education institution to the development of the nation and its well-being is essential to becoming a high impact nation. Thus, the affordability of tertiary education to people from all backgrounds is important to achieve this vision. Many governments all over the world have faced such an issue. The level of education debt differs a lot depending on the type of institution a particular student is attending. According to Zainal and Ismail (2011), those students who attend private colleges and universities borrowed the most amount of loan with an average of RM 53,750 and RM 31,324 respectively. These figures are most likely to increase year by year as mentioned by Benjamin et al. (2011), a study showed in the USA tuition fees and other fees have been increasing much faster than the cost of other goods over the last decade or so. The combination of rising costs of higher education and the higher costs of living will make education loans a necessity. Such prospects are worrying, and most likely the prediction is that this will continue in the future. 


\section{Theory of Reasoned Action (TRA)}

TRA is a model for the prediction of behavioural intention, spanning predictions of attitude and predictions of behaviour. The subsequent separation of behavioural intention from behaviour allows for an explanation of limiting factors on attitudinal influence (Ajzen, 1980). Fishbein in 1975 and Ajzen developed this model in 1980 that led to the study of attitudes and behaviours. This research applied the TRA model to investigate the process that leads to the decision of whether or not to repay a certain loan. The TRA states that the direct forerunner of the decision is loan repayment intention. This will later translate to the actual behaviour of repayment of loan depending on the degree of the student's evaluation that perceives it as negative or positive.

\section{Attitude of Students toward PTPTN Loan Repayment and Intention to Pay}

According to Ismail et al. (2011), the problems in regards to attitude towards loans are seldom touched and understood. This is mainly due to research on attitude were more focused in the field of psychology, and not on finance or debt management. Graduates that have debts are facing difficulties in making repayment of their education loans. What becomes a serious issue is that they are servicing other debts as well (Zainal \& Ismail, 2012). As mentioned in a previous study by Price (2004), a student is a loan defaulter when he or she has a debt load that is above $8 \%$. The study also found that students that have a high educational debt have lower salaries in average compared to other students. Therefore, the amount of default can be a good gauge when predicting the amount of repayment.

\section{The link between attitudes towards education loans repayment.}

TRA contains two essential variables, Attitude and Perception of loan repayment as a burden towards loan repayment intention. A student's attitude is the individual's positive or negative feelings (evaluative affect) about loan repayment. The users' desirability and salient beliefs will construct their feelings towards the loan and predict a user's intention (Ismail et al., 2011). As observed, attitudes have the incentives to repay the loan. These observations suggest the following hypothesis. 
Hypothesis 1: Attitude towards education loan repayment has a positive relationship with intention to repay PTPTN loan.

The link between awareness of PTPTN by the media towards education loan repayment

Ismail et al. (2011) explained that the students who are managing their awareness on the loan issues could ensure the efficient use of the money borrowed during their studying years as well as after graduating. Issues created by the media have a positive relationship with loan repayment. Therefore, the following hypothesis is developed:

Hypothesis 2: Awareness of PTPTN issues created by the media has a positive relationship with intention to repay PTPTN loan.

The link between perceived affordability of repayment after graduating towards education loan repayment.

The third hypothesis accommodates the incorporation of perceived quality and affordability of living after graduating. It refers to the effects of any diminishing in the quality of living to cope with the affordability of repaying the loan. In other words, borrowers are more likely to prioritise other factors that immediately affect their lives that are more important, i.e., spending or repayment; this includes mortgages, car loans, and other costs incurring lifestyle decisions.

Hypothesis 3: Perceived affordability of repayment after graduating has a positive relationship with intention to repay PTPTN loan.

The link between perceptions towards loan agreement towards education loan repayment.

The personal perception about loan agreements whether the borrowers understand the agreement well or not could affect loan repayment after graduation, legal consequences for defaulters and their future livelihood. In this regard, the following hypothesis is developed:

Hypothesis 4: Perception towards loan agreement has a positive relationship with intention to repay PTPTN loan. 


\section{Research Frameworks}

This study examines the influencing factors of education loan repayment in Malaysia. Based on the literature review, it was proposed that the study will use a simplified Theory of Reasoned Action (TRA) to illustrate the fundamental processes that lead to loan repayment decisions as what has been introduced by Ismail et al. (2011). Furthermore, the TRA model states that the loan repayment intention is the immediate precursor of the decision of repayment (Ismail et al., 2011). The model (Figure 3.1) summarised the relationship between four independent variables and one dependant variable that is the fundamental framework of the study. The independent variables consist of 'Attitude towards Education Loan Repayment' (Attitude), 'Awareness of PTPTN Issues by the Media' (Awareness), 'Perceived Affordability of Repayment after Graduating' (Perception of affordability) and 'Perception of Loan Agreement'. The 'Intention to repay PTPTN Loan' has been identified as the dependent variable. The SPSS was used to analyse the data gathered from the respondents, and the standard multiple regression was applied to study the relationships between each other.

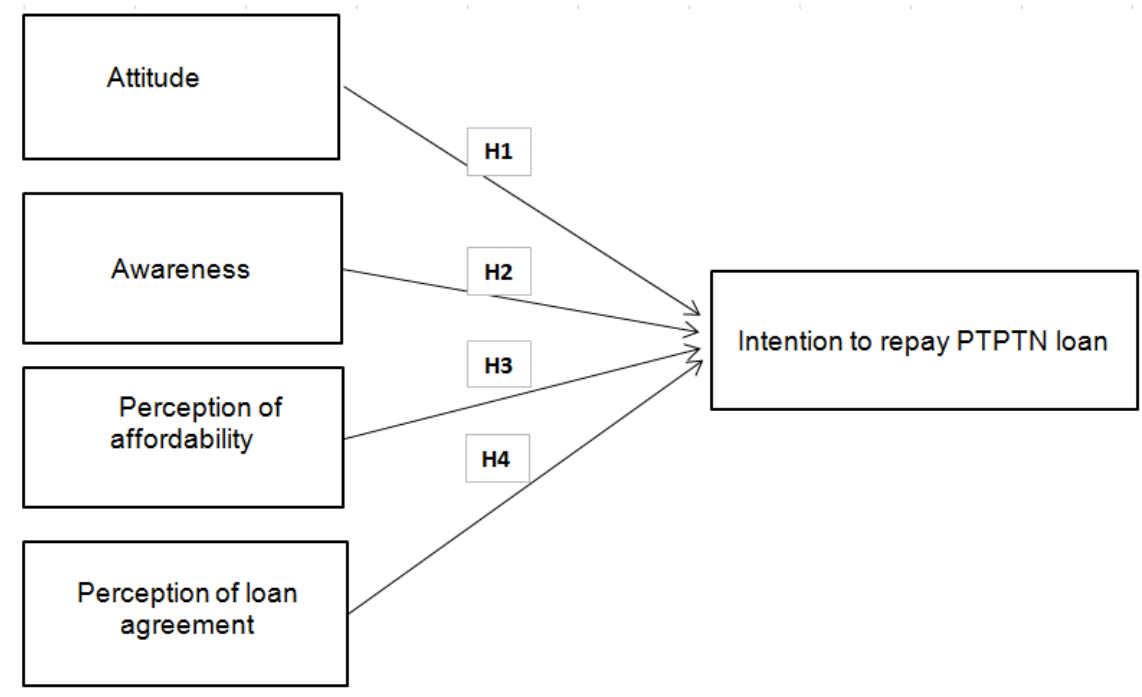

Figure 1: Proposed Research Framework

\section{Methodology}

Sampling design and data collection procedure: This research employed a descriptive design to support the study of hypotheses presented. The survey 
instrument used involved a combination of specific questionnaires for each of the area of attitude, awareness, perception of affordability, the perception of the loan agreement and included demographic variables.

These self-administered questionnaires were distributed to a convenient sample of 300 graduates from one of the leading public universities in Malaysia, using non-probability sampling methods.

Data analysis techniques: The data was analysed using the Statistical Package for Social Sciences (SPSS) version 16.0 program. A code was established for each variable before input into the program.

All Likert Scale points for all questions under a particular measure were summed to produce a new variable.

The following derived measures from the summing of the Likert Scale points of the respective questions were:

- attitude

- awareness

- perception of affordability

- perception of the loan agreement

The data analysis consisted of the following parts:

- Test of normality for each variable using the Descriptive Numerical Method of Skewness and Kurtosis statistics.

- For a test of scale reliability, used was Cronbach's coefficient alpha.

- In determining the relationship between each dimension of the variables with the education loan repayment program, the Pearson correlation coefficient analysis was used.

- In determining the linear composite relationship between the above four variables concerning participation in the education loan repayment, the program used was Multivariate statistical technique for all variables regression.

\section{Results}

\section{Profile of respondents}

The majority of the respondents are female $(58.8 \%)$ while the remaining are male respondents (41.2\%). Most of the respondents fall within the age group of $30-39$ years $(56.4 \%)$, followed by those aged from $20-29$ years $(34.8 \%)$. Singles consist of $45.2 \%$ while the rest are married. The majority of them hold a Bachelor's degree and most of the respondents are earning between RM3001$6000(48.4 \%)$ followed by those earning between $6001-9000$ (36.4\%). A 
distribution of them graduated from public universities and had PIPTN loan. Table 1 below, shows the summary of the respondents' profile.

Table 1: Participant profile

\begin{tabular}{|c|c|c|}
\hline Characteristics & Frequency & Percent \\
\hline \multicolumn{3}{|l|}{ Gender } \\
\hline Male & 103 & $41.2 \%$ \\
\hline Female & 148 & $58.8 \%$ \\
\hline \multicolumn{3}{|l|}{ Age } \\
\hline $20-29$ & 87 & $34.8 \%$ \\
\hline 30-39 & 141 & $56.4 \%$ \\
\hline $46-49$ & 12 & $4.8 \%$ \\
\hline Above 50 & 10 & $4.0 \%$ \\
\hline \multicolumn{3}{|l|}{ Marital status } \\
\hline Single & 113 & $45.2 \%$ \\
\hline Married & 137 & $54.8 \%$ \\
\hline \multicolumn{3}{|l|}{ Ethnic } \\
\hline Malay & 186 & $74.8 \%$ \\
\hline Chinese & 41 & $16.4 \%$ \\
\hline Indian & 23 & $9.2 \%$ \\
\hline \multicolumn{3}{|l|}{ Qualification } \\
\hline Doctorate degree & 0 & $0.0 \%$ \\
\hline Master's degree & 68 & $27.2 \%$ \\
\hline Bachelor's degree & 182 & $72.8 \%$ \\
\hline Diploma/certificate & 0 & $0.0 \%$ \\
\hline \multicolumn{3}{|l|}{ Occupation } \\
\hline Full time student & 41 & $16.4 \%$ \\
\hline Private sector & 194 & $77.6 \%$ \\
\hline Government sector & 15 & $6.0 \%$ \\
\hline Own Business & 0 & $0.0 \%$ \\
\hline Unemployed & 0 & $0.0 \%$ \\
\hline \multicolumn{3}{|l|}{ Monthly Income } \\
\hline RM3000 and below & 17 & $6.8 \%$ \\
\hline RM3000-RM6000 & 121 & $48.4 \%$ \\
\hline RM6001-RM9000 & 91 & $36.4 \%$ \\
\hline RM9001-RM11000 & 21 & $8.4 \%$ \\
\hline RM11000 above & 0 & $0.0 \%$ \\
\hline \multicolumn{3}{|l|}{ Place of Study } \\
\hline Public University & 189 & $75.6 \%$ \\
\hline Private Uni/College & 61 & $24.4 \%$ \\
\hline \multicolumn{3}{|l|}{ Have PIPTN loan } \\
\hline Yes & 169 & $67.6 \%$ \\
\hline No & 81 & $32.4 \%$ \\
\hline
\end{tabular}




\section{Normality test}

The normality of all the variables was tested by assessing the skewness and kurtosis values. When data is normally distributed, the value of skewness and kurtosis are zero, as values outside the range of +2 or -2 demonstrate significant degrees of non-normality (George and Mallery, 2003). In this study, most of the variables were inside the range of +2 or -2 as shown in Table 2 .

Table 2: Normality test

\begin{tabular}{lcc} 
Variable & Skewness & Kurtosis \\
\hline AA1 & 0.189 & -0.778 \\
AA2 & -0.193 & -0.202 \\
AA3 & -0.146 & -0.689 \\
AA4 & -0.258 & -0.279 \\
AA5 & 0.290 & -0.911 \\
AC1 & 0.028 & -0.258 \\
AC2 & 0.000 & 2.278 \\
AC3 & 0.066 & -0.385 \\
PA1 & 0.709 & 0.670 \\
PA2 & 0.620 & 0.719 \\
PA3 & 0.639 & 0.311 \\
PL1 & 0.642 & 0.334 \\
PL2 & 0.201 & 0.515 \\
PL3 & 0.533 & 0.277 \\
PL4 & 0.209 & -0.176 \\
PL5 & 0.115 & -0.252 \\
PL6 & 0.232 & -0.260 \\
PL7 & 0.072 & -0.280 \\
PL8 & -0.203 & -0.293 \\
\hline
\end{tabular}

\section{Reliability test}

Cronbach's coefficient alpha was used to measure the internal consistency of scale. Its value ranges from $0-1$ (Table 3). The tests of reliability were performed on all the measures used. Table 3 below, summarised the Cronbach's coefficient alpha for each measure. A scale is reliable if the coefficient value is more than 0.600 (Hair et al., 1998).

Table 3: Reliability of measures

\begin{tabular}{lll}
\hline Measure & $\begin{array}{l}\text { Number } \\
\text { of items }\end{array}$ & $\begin{array}{l}\text { Cronbach's } \\
\text { coefficient alpha }\end{array}$ \\
\hline & & \\
Attitude (A1) & 5 & 0.897 \\
Awareness (A2) & 3 & 0.806 \\
Perception of affordability (PA) & 3 & 0.914 \\
Perception of loan agreement (PL) & 8 & 0.879 \\
\hline
\end{tabular}


All the measures in this study were found to be reliable with the intention to leave scale having the highest coefficient alpha value of 0.914 . The measure having reliability coefficients lower than 0.700 was normative commitment.

Hypothesis 1: Attitude towards education loan repayment has a positive relationship with intention to repay PTPTN loan.

Hypothesis 2: Awareness of PTPTN issues created by the media has a positive relationship with intention to repay PTPTN loan.

Hypothesis 3: Perceived affordability of repayment after graduating has a positive relationship with intention to repay PTPTN loan.

Hypothesis 4: Perception towards loan agreement has a positive relationship with intention to repay PTPTN loan.

Pearson correlation coefficient analysis was used to determine the relationship between attitude, awareness, perception of affordability, and perception of the loan agreement and education loan repayments. The Pearson Correlation coefficient, which indicates the strength of relationship between the variables will show the following: a correlation coefficient between 0.10 and 0.29 indicate a small correlation, while a coefficient between 0.30 and 0.49 indicate a medium correlation and a coefficient between 0.50 and 1.0 indicate a large correlation (Sidin and Zawawi, 2002).

In this study, the Pearson Correlation coefficient ( $r$ ) between dimensions of attitude, awareness, perception of affordability, perception of the loan agreement and education loan repayment for $\mathrm{H} 1, \mathrm{H} 2, \mathrm{H} 3$ and $\mathrm{H} 4$ were as follows:

$\mathrm{H} 1, \beta=0.320, \mathrm{p}>0.05 ; \mathrm{H} 2, \beta=-0.031, \mathrm{p}>0.05 ; \mathrm{H} 3, \beta=-0.339, \mathrm{p}>0.05$ and $\mathrm{H} 4, \beta=-$ $0.331, \mathrm{p}>0.05$. Therefore, hypotheses H1, H3 and H4 were fully supported.

Table 4: Pearson correlation between all dimensions of variables

\begin{tabular}{lr}
\hline Attitude two loan repayment & 0.302 \\
Awareness of PTPN loan & -0.031 \\
Perception of affordability & 0.339 \\
Perception of loan agreement & 0.330 \\
\hline
\end{tabular}


H1: Attitude towards education loan repayment has a positive relationship with intention to repay PTPTN loan. Supported

H2: Awareness of PTPTN issues created by the media has a relationship with intention to repay PTPTN loan. Not Supported (Not Significant)

H3: Perceived affordability of repayment after graduating has a relationship with intention to repay PTPTN loan. Supported

H4: Perception towards loan agreement has a relationship with intention to repay PTPTN loan.Supported

This research revealed that four of the determining factors that concern the attitude towards an education loan repayment and perception of affordability of loan repayment would affect the quality of life after graduation and perception towards loan agreement. All of these independent variables were supported about the effectiveness and efficiency of education loan repayment program.

RQ1: What are the factors influencing intention of loan repayment among graduates?

There were three factors that influenced the intention of loan repayments among graduates. The factors identified are: attitude towards education loan repayment, the perception of affordability of a loan repayment affects the quality of life after graduation and the perception towards loan agreements. The perception of affordability and understanding the loan agreement were identified as the most crucial factors that influenced a graduate's intention of loan repayment. Therefore, it is important for PTPTN to ensure to explain to borrowers the terms regarding the loan agreement when approving a loan. PTPTN must spend more effort to educate or simplify the agreement or both so that borrowers understand the loan contract. PTPTN must also educate students on the implications of failing to repay their loans. As for students, proper financial planning is important to ensure that they are not trapped in debt.

RQ2: Do the graduates' attitudes and perceptions towards PTPTN loans and the repayment of PTPTN loans affect the intention to pay?

A Graduate's attitude and perceptions towards the PTPTN loan do affect the intention to repay. PTPTN needs to find ways to minimise the negative perception associated with loan repayments. One of the possible ways is through collaboration with the other organisations or institutions of higher 
learning in Malaysia, as well as providing incentives, a more flexible repayment schedule and taking sterner actions that would certainly deter defaulters and encourage more people to repay their loans.

\section{Implications of these Research Findings}

The findings from this study have revealed the influencing factors of loan repayment intention. It is hoped that the findings could assist the National Higher Education Fund Corporation (PTPTN), to further understand the borrower's insights in repaying the loans. PTPTN benefits from this regarding the following:

a) The information would be useful to the corporation to work together with the institutions of higher learning to carry out seminars, talks and other programs to change the mindset of the students.

b) The policy makers and management of PTPTN (Corporation) could reevaluate the terms and conditions of the loan agreement so that the students do not feel the immediate burden of repayments after graduating.

c) PTPTN would be able to develop a more comprehensive strategy to suit the market expectations and ensuring that the amount of loan approved is adequate for borrowers.

From the Ministry of Higher Education point of view, the findings from this study could assist in the formulation and implementation of new financial policies and aid in the direction of higher education in Malaysia. This will help to turn Malaysia into a premier destination for higher education as shown in Table 5.

Table 5: Summary of the findings

\begin{tabular}{|c|c|c|c|c|}
\hline Pro & & & & \\
\hline $\begin{array}{l}\text { The number of } \\
\text { students } \\
\text { taking up PTPTN } \\
\text { loans is increasing } \\
\text { year after } \\
\text { year, it is important } \\
\text { for } \\
\text { PTPTN funding to } \\
\text { be } \\
\text { replenished and }\end{array}$ & $\begin{array}{l}\text { a)What are } \\
\text { the factors } \\
\text { influencing } \\
\text { intention of } \\
\text { loan re- } \\
\text { payment } \\
\text { among } \\
\text { graduates? }\end{array}$ & $\begin{array}{l}\text { a) To discover } \\
\text { the factors } \\
\text { that influences } \\
\text { the } \\
\text { intention of } \\
\text { loan } \\
\text { repayment } \\
\text { among } \\
\text { graduates. }\end{array}$ & $\begin{array}{l}\text { H1: Attitude } \\
\text { towards } \\
\text { education loan } \\
\text { repayment has } \\
\text { a positive } \\
\text { relationship } \\
\text { with intention } \\
\text { to repay } \\
\text { PTPTN loan. }\end{array}$ & $\begin{array}{l}\text { H1: Supported } \\
\text { due to } \\
\text { significant } \\
\text { finding based } \\
\text { on the analysis } \\
\text { conducted }(\beta= \\
0.302, p<0.05) .\end{array}$ \\
\hline
\end{tabular}




\begin{tabular}{|c|c|c|c|c|}
\hline $\begin{array}{l}\text { have sufficient } \\
\text { funding for future } \\
\text { generations. } \\
\text { However, due to } \\
\text { the } \\
\text { undistinguished } \\
\text { repayments among } \\
\text { graduates, it will } \\
\text { have an immediate } \\
\text { impact on PTPTN } \\
\text { running out of } \\
\text { funds for future } \\
\text { students }\end{array}$ & $\begin{array}{l}\text { b) Do the } \\
\text { graduates.' } \\
\text { attitudes and } \\
\text { perceptions } \\
\text { towards } \\
\text { PTPTN loan } \\
\text { and } \\
\text { the } \\
\text { repayment of } \\
\text { PTPTN } \\
\text { Loan affect } \\
\text { the intention } \\
\text { to pay? }\end{array}$ & $\begin{array}{l}\text { b) To } \\
\text { determine the } \\
\text { relationship } \\
\text { between } \\
\text { graduates' } \\
\text { attitudes and } \\
\text { graduates' } \\
\text { perception } \\
\text { towards } \\
\text { intention of } \\
\text { PTPTN loans } \\
\text { repayment. } \\
\text { c) To examine } \\
\text { the effect } \\
\text { of graduates' } \\
\text { attitudes } \\
\text { and } \\
\text { perceptions on } \\
\text { the } \\
\text { intention to } \\
\text { repay } \\
\text { education } \\
\text { loans. }\end{array}$ & $\begin{array}{l}\text { H2: Awareness } \\
\text { of } \\
\text { PTPTN issues } \\
\text { by the } \\
\text { media has a } \\
\text { relationship } \\
\text { with the } \\
\text { intention to } \\
\text { repay PTPTN } \\
\text { loan. } \\
\text { H3: Perceived } \\
\text { affordability of } \\
\text { repayment } \\
\text { after } \\
\text { graduating has } \\
\text { a relationship } \\
\text { with intention } \\
\text { to repay } \\
\text { PTPTN loan. } \\
\text { H4: Perception } \\
\text { towards loan } \\
\text { agreement has } \\
\text { a relationship } \\
\text { with intention } \\
\text { to repay } \\
\text { PTPTN loan. }\end{array}$ & $\begin{array}{l}\text { supported due } \\
\text { to an } \\
\text { insignificant } \\
\text { finding based } \\
\text { on the analysis } \\
\text { conducted }(\beta= \\
-0.031, p>0.05) \text {. }\end{array}$ \\
\hline
\end{tabular}

\section{Suggestion for future research}

From the Malaysia's context, more studies and research are needed to be done to determine other potential variables that would influence the loan repayment intention. As Malaysia is a multiracial country and enjoys a diverse culture, studies dealing with the influences of other demographic factors, such as religion and location, on the subject matter are needed.

\section{Conclusion}

Based on the findings derived from this study, a few recommendations can be proposed regarding pragmatism. Firstly, the findings can be useful for PTPTN regarding revealing factors that influence the behaviour and attitude of 
graduates towards repayment of loans so that the PTPTN better understands the problems of non-repayment of educational loan among Malaysian student clients. PTPTN together with the educational institutions must educate and instil the necessary values in the students with an emphasis that repaying the loan is their responsibility, a demand to change their attitude towards such debt. This is to ensure that the PTPTN fund is sufficient financially to help other students to pursue their education. Secondly, most graduates do not have a strong financial capacity upon graduation, therefore, providing some form of deferment or scheduled repayment scheme would be beneficial to both parties. A graduate who is allowed to wait until their financial situations are stable before starting to commit to repaying the loan is probably more positive in repaying it as part of their current living expenses. At the same time, by lending out smaller amounts of loan, PTPTN will ensure that the burden of repayment will not be onerous for the borrowers. Thus, PTPTN should revise and review the loan amount accordingly. As the Ministry of Education of Malaysia is the entity responsible for Malaysian educational matters, it can use this research to assist PTPTN to better understand a borrower's needs and expectations, and this would influence repayments. A more comprehensive policy that would benefit both the PTPTN and the students could be developed to promote and increase repayments. By having a comprehensive approach and strategies, PTPTN would be able to reduce the number of defaulters. At the same time, it could enhance the effectiveness of their collection activities. In the development of new products and services, PTPTN must emphasise the positive attitudes and perceptions of the new products towards making repayments and thus add to the pool of available PTPTN funds.

Acknowledgements: This research is sponsored by University UMRG grants.

\section{References}

Abu Bakar, E., Masud, J. and Jusoh, M.Z. (2006), Knowledge, attitude and perceptions of university students towards educational loans in Malaysia, Journal of Family Economics Issue, Vol. 27, pp. 692-701.

Ajzen, I. and Fishbein, M. (1980), Understanding Attitudes and Predicting Social Behaviour, Prentice-Hall, Englewood Cliffs, NJ. 
Benjamin, S. J., Marathamuthu, M. S., Muthaiyah, S. and Raman, M. (2011), Affordability of private tertiary education: a Malaysian study, International Journal of Social Economics Vol. 38 No. 4, 2011 pp. 382-406.

Fishbein, M. and Ajzen, I. (1975), Belief, Attitude, Intention, and Behaviour: An Introduction to Theory and Research, Addison-Wesley, Reading, MA.

George, D. and P. Mallery, (2003). Frequencies. In: SPSS for Windows Step by Step: A Simple Guide and Reference 11.0 Update, George D. and P. Mallery (Eds.), 4th Edn., Pearson Education, New York. Pp: 20-52.

Ghazali, R. (2013), Cabinet says no to black listing PTPTN defaulters on CCRIS. Retrieved from http://www.thestar.com.my/News/Nation/2013/08/21/ptptncabinet. aspx

Hair, J.F., R.E. Anderson, R.L. Tatham and W.C. Black (1998). Multivariate Data Analysis 5th Edn. Upper Saddle River, N.J. Prentice Hall. Pp: 169215.

Ismail, S., Serguieva, A. and Singh, S. (2011), Integrative model of students' attitude to educational loan repayment: A structural modelling approach, Journal of International Education in Business Vol. 4 No. 2, 2011 pp. 125-140.

Sidin, S.M. and D. Zawawi (2002). The relationship between organisational commitment and job performance amongst executives in Malaysia. Proceedings of the Asia Pacific Economics and Business Conference, pp: 937-945.

Zainal, N. R. and Ismail, N. (2012), Debt Composition of University Graduates and Their Attitude Towards Education Loan, Journal of Asian Behavioural Studies, Volume 2, Number 6, July 2012. 